Iran Journal of Nursing (IJN)

Vol 32, No. 118, Jun 2019: 50- 61

\title{
Fear of Falling and Its Contributing Factors in the Elderly with the History of Orthopedic Surgery
}

\author{
Saeedeh Hajati ${ }^{1},{ }^{*}$ Farideh Bastani ${ }^{2}$
}

\begin{abstract}
Background \& Aims: Old age is associated with several health threats, including falls, with fear of falling considered to be one of its major complications, especially after orthopedic surgeries, which may lead to limited daily activities, isolationism, and lack of social participation. The present study aimed to assess the fear of falling and its contributing factors in the elderly patients with the history of falls following orthopedic surgeries, who referred to the orthopedic clinics of selected hospitals affiliated to Iran University of Medical Sciences.

Materials \& Methods: This cross-sectional, descriptive-correlational study was conducted on 280 elderly patients referring to the clinics of the hospitals in Tehran, Iran. The patients were selected via convenience sampling. Data were collected using the abbreviated mental test (AMT), a demographic questionnaire, and the falls efficacy scale instrument (FES-I), which were completed via face-to-face interviews with the elderly. Data analysis was performed in SPSS version 20 using descriptive and inferential statistics, independent t-test, oneway analysis of variance (ANOVA), and linear regression analysis at the significance level of $\mathrm{P} \leq 0.05$.

Results: The mean age of the elderly was $69.50 \pm 4.29$ years, and $65 \%$ and $35 \%$ of the patients were female and male, respectively. The results of Pearson's correlation-coefficient indicated a direct correlation between the fear of falling and age $(\mathrm{P}=0.008 ; \mathrm{r}=0.159)$. Direct, significant correlations were also observed between the fear of falling and hypertension, the number of the used medications, and pelvic fractures $(\mathrm{P}<0.05)$. In addition, $97.9 \%$ of the patients had more than one orthopedic surgery, which was directly correlated with the fear of falling.

Conclusion: According to the results, the frequency of fear of falling in the elderly with the history of orthopedic surgeries was significantly high. Considering the adverse outcomes of the fear of falling in elderly patients, it is recommended that counseling training programs be planned for the elderly patients after orthopedic surgeries for the health promotion of these individuals and active old age, as well as the reduction of the fear of falling in elderly patients.
\end{abstract}

Keywords: Elderly, Fear of Falling, Falling, Orthopedic Surgery

\section{Conflict of Interest: No}

How to Cite: Hajati S, Bastani F. Fear of Falling and Its Contributing Factors in the Elderly with the History of Orthopedic Surgery Iran Journal of Nursing. 2019; 32(118):50-61.

Received: 11 March 2019

Accepted: 15 Jun 2019

\footnotetext{
1. MS Student in Geriatric Nursing, School of Nursing and Midwifery, Iran University of Medical Sciences, Tehran, Iran

2. Professor, Department of Public Health Nursing and Geriatrics, School of Nursing and Midwifery, Iran University of Medical Sciences, Tehran, Iran (*Corresponding author) Tel: $02143651800 \quad$ Email: bastani.f@iums.ac.ir
} 


\title{
ترس از سقوط و عوامل مرتبط با آن در سالمندان با سابقه جراحى ارتويدى
}

\author{
سعيده حاجتى '، **فريده باستانى
}

جكيده

زمينه و هدف: سالمندى با عوامل متعلد تهلديد كننده سلامت از جمله سقوط همراه است كه بديده "ترس از سقوط" از عوارض آن محسوب مىشود،

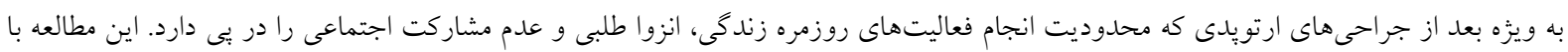

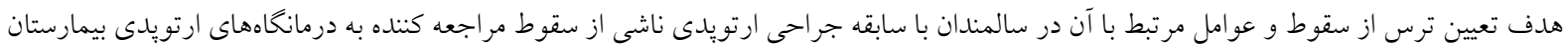

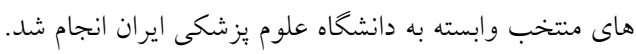

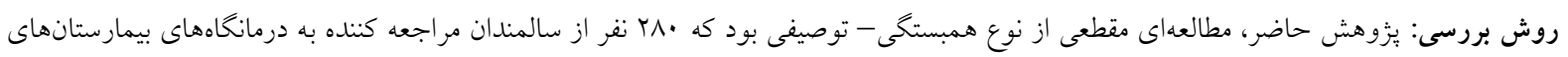

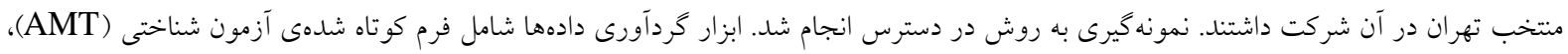

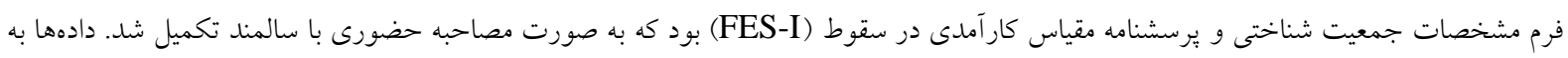

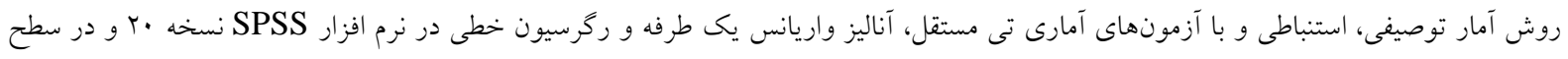

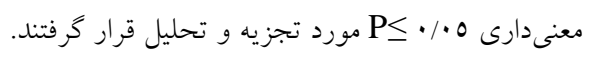

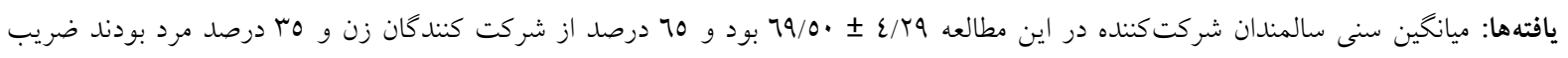

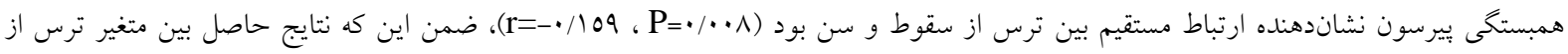

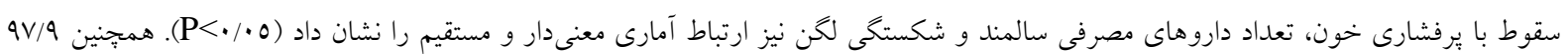

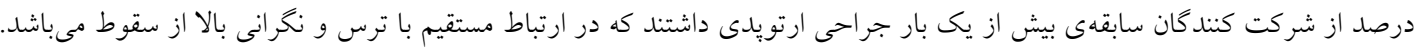

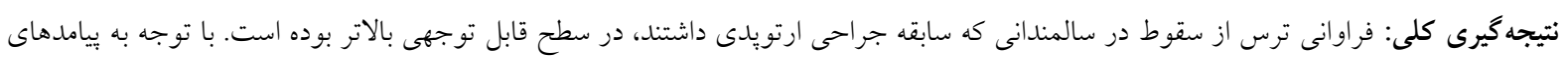

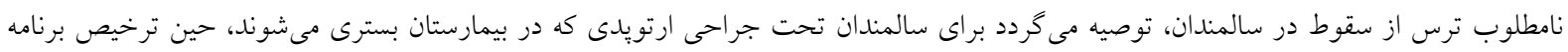

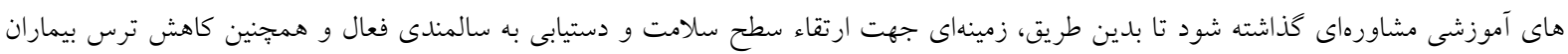
سالمند از سقوط فراهم آيد.

كليد وازهها: سالمند، ترس از سقوط، سقوط، جراحى ارتويدى تعارض منافع: ندارد

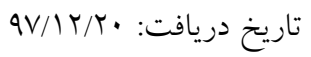

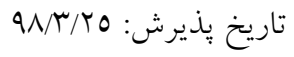

\footnotetext{
(:ن:نويسنده مسئول)
}

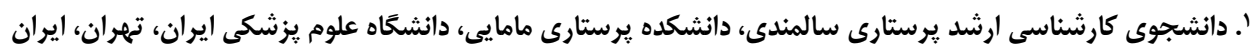

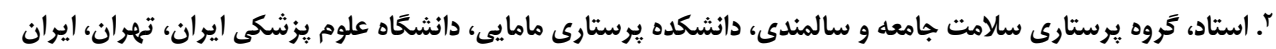


دارند (9). با توجه به تعداد افر اد سالمند ايرانى كه در معرض

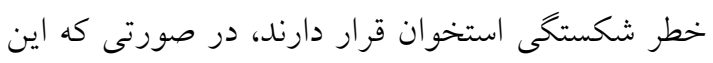

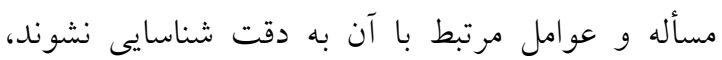

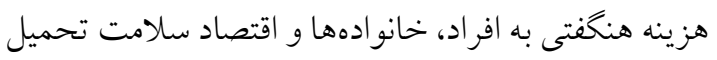
خواهد شد. بنابراين براى اتخاذ راهبردهاى بيشخير آنهانه

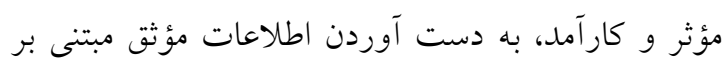

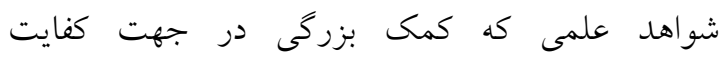

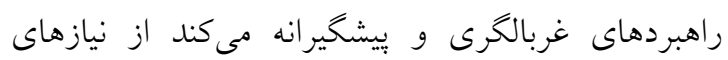

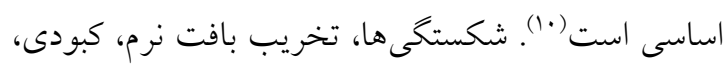

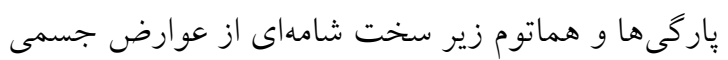
متداول سقوط در سالمندان است. هزينه مراقبتهاى

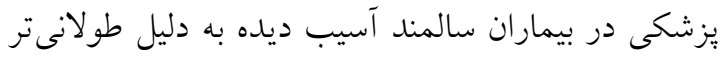
بودن مدت زمان بسترى و نياز به مراقبتهاى ويزه، سه

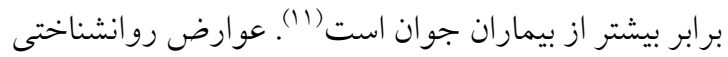
سقوط شامل كاهش اعتماد به نفس، كاهش اميد به زندگى،

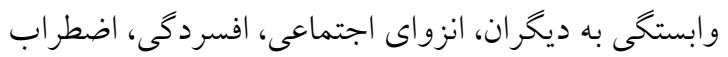

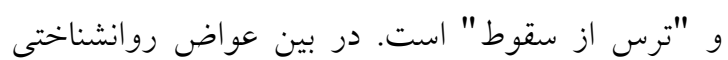

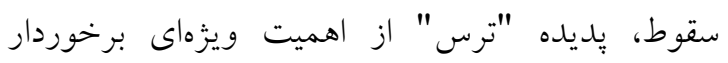
است (ع). ترس از سقوط رايجترين ترس در سالمندان است، به اين معنى كه افرادى كه ترس از سقوط دارند،

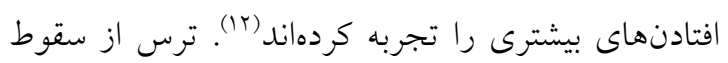

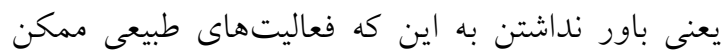

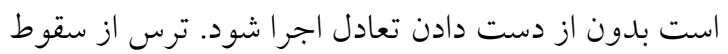

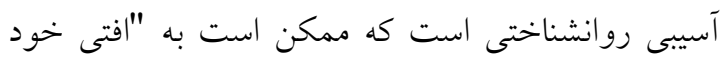

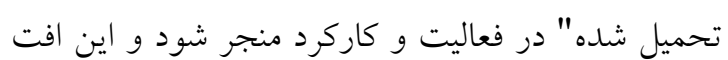

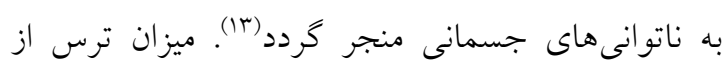
سقوط در جوامع سالمندان حدود Mr-09 درصد

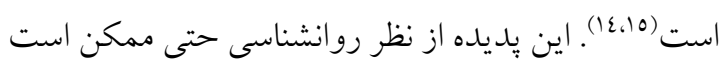
به لحاظ بيامدهاى نامطلوب آن، از تجربه يكى سقوط هم مضرتر باشد (17). ترس از سقوط به عنوان يك نخرانى دائمى درباره سقوط باس كه نهايتًا ممكن است فعاليتهاى روزمره زندكى (ADL)

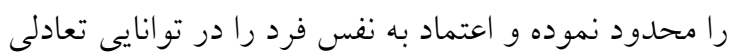

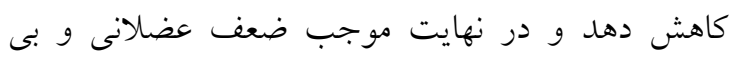

\section{مقدمه}

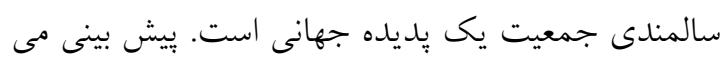

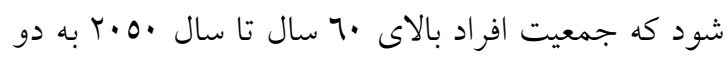

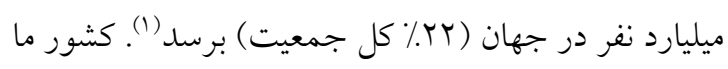
نيز از اين قاعده مستنى نيست. در ايران جمعيت بالاتر از

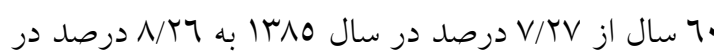

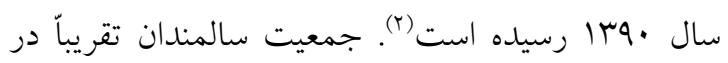
همه كثورهاى جهان به دليل كاهش نرخ بارورى و

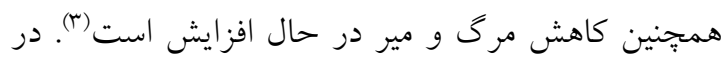
اين بين عوامل متعددى به عنوان تهايد كننده سلامت سالمندان، افت كيفيت زندگى و بالا رفتن هزينههاى نغهارى آنان مورد توجه قرار كرفته است. از جمله عواملى كه با افزايش سن احتمال وقوع آن بيشتر مىشوده، بديده سقوط سالمندان است كه آنها را در معرض افزايش

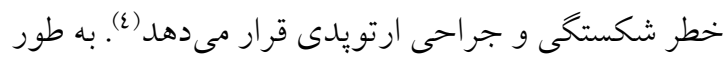

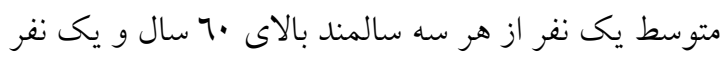
از هر دو سالمند بالاى •^ سال، حداقل يك بار در سال

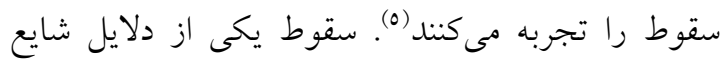
حضور سالمندان در بخش اورزانس است. به طورى كه

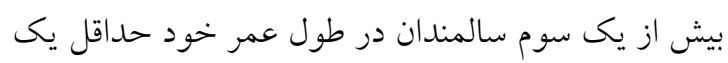

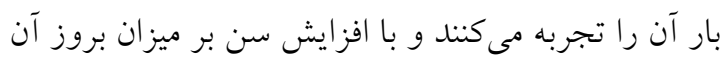

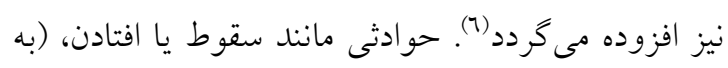

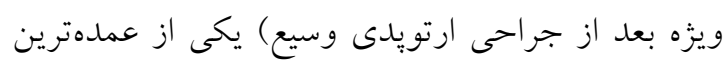

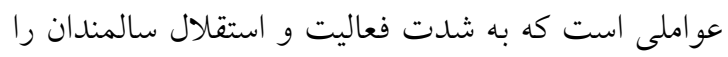

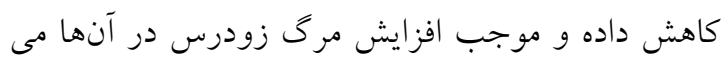

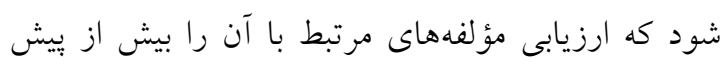
ضرورى مى نمايد (v) حدود يكى سوم تا نيمى از سالمندان در طول سال سقوط هـ

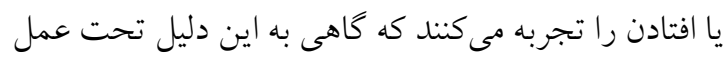
جراحى ارتويدى قرار مى كيرند و بعد از جر احى به ته تدريج

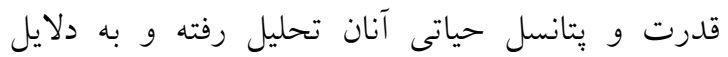

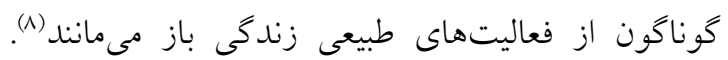

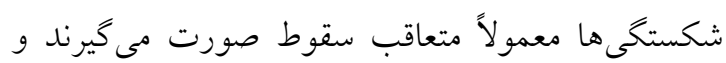
درصد قابل توجهى از اين بيماران به اقدامات جراحى نياز 
اساس يروندهى بيمار، توان برقرارى ارتباط و نداشتن

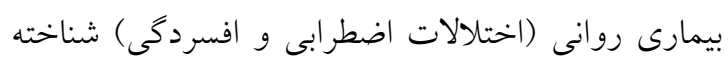
شده (بر اساس اظهارات خانواده يا برونده بيمار) بود.

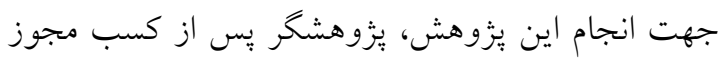

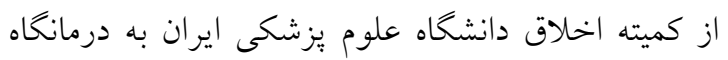
هاى ارتويدى بيمارستانهاى منتخب مر اجعه نموده و بعد

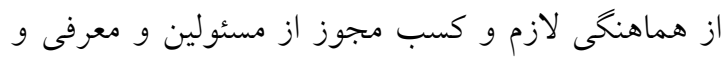

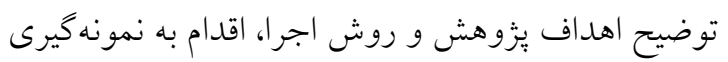

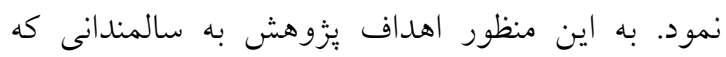

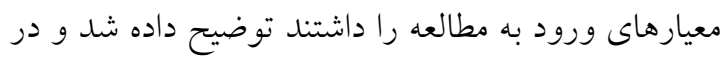
صورت تمايل براى شركت در يُزوهش، فرم رضايت

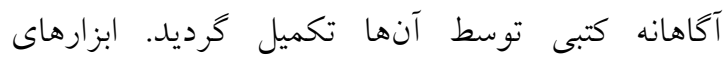
كردآورى دادهها شامل فرم مشخصات جمات جمعيت شناختى

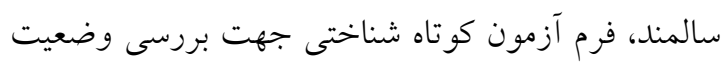

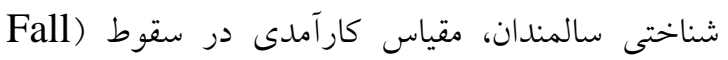
جهت تعيين ترس از سقوط سالمند (efficacy scale -I

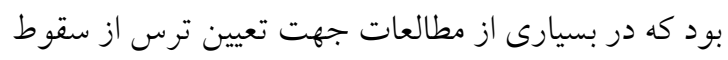

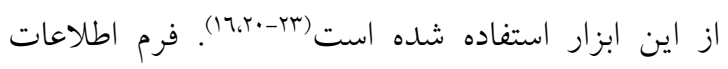
جمعيت شناختى و ويزگگ هاى بالينى كه شامل اطلاعاتى إنى از قبيل سن، جنسيت، سطح تحصيلات، وضعيت اشتغال،

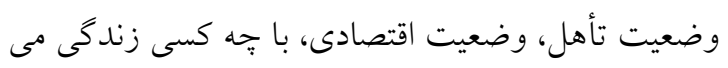

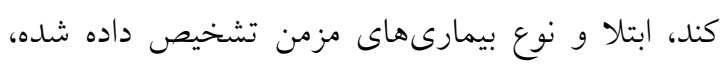

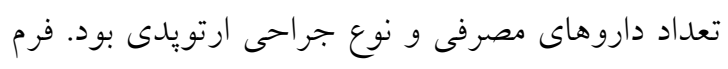

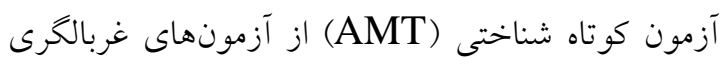

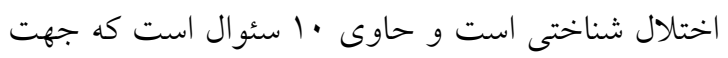

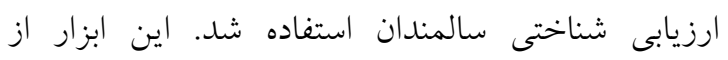

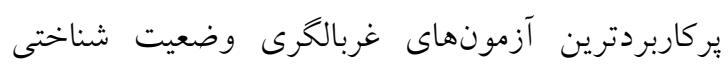

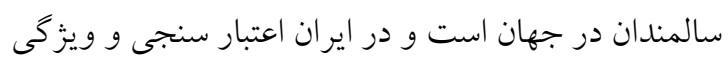

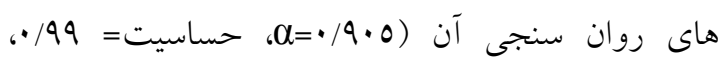

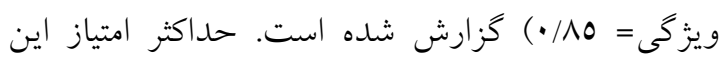

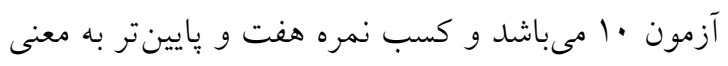
وجود اختلال شناختى است. اين آزمون تشخيص افراد

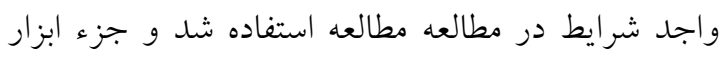
هاى اصلى مطالعه تلقى نمىشود، يرسشنامه (FES-I)
تحركى و كاهش كيفيت زندكى سالمند شود، توصيف شده

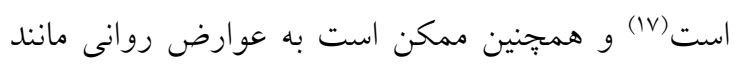

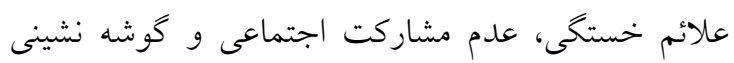

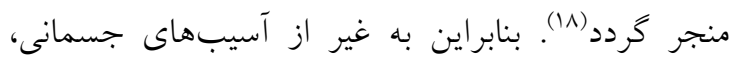
آسيبهاى روانى هم ممكن است در نتيجهى ترس از

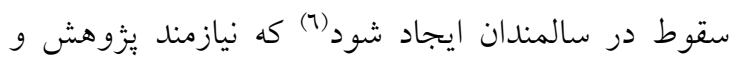
مطالعات در فرهنگهاى مختلف مىباشد. از آنجا كه ترس دئد از سقوط به عنوان يك وضعيت روانى و محدود كنندهى

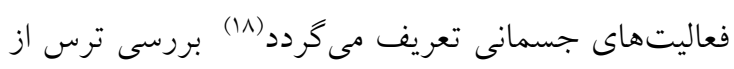

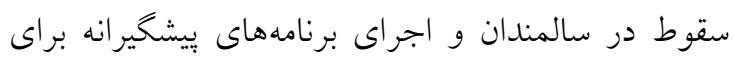

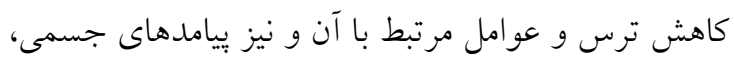

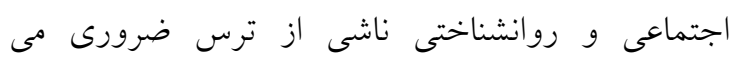

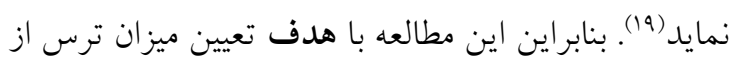

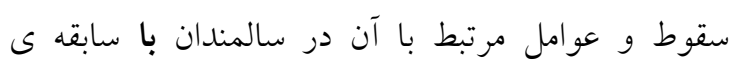
جراحى ارتويدى ناشى از سقوط مر اجعه كننده به درمانگاه

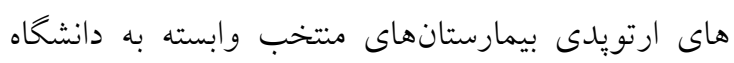
علوم يز شكى ايران انجام گرفت.

يزّوهش حاضر مقطعى از نوع همبستخى_ توصيفى است.

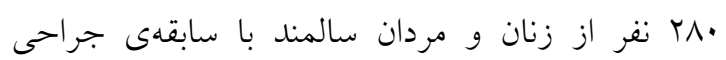

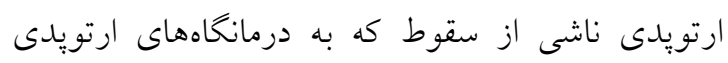

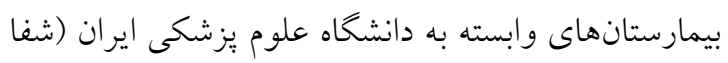

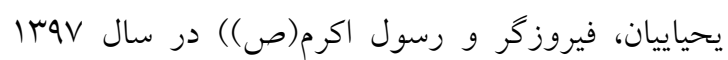

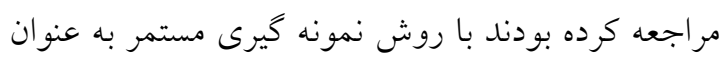

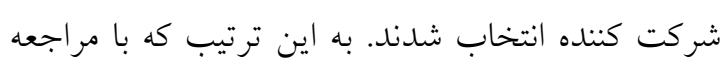

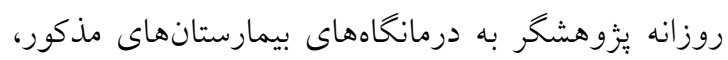

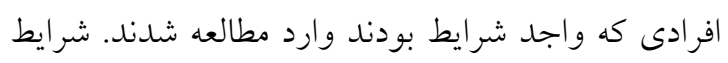

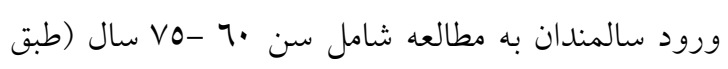
طبقه بندى WHO سالمندان جوان مد نظر بوده است)،

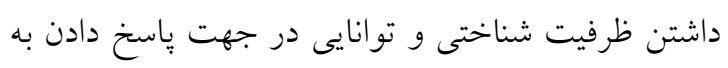
سوالات كه از طريق مقياس ( Abbreviated Mental AMT (Test

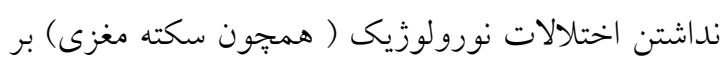


آمار استنباطى (تى مستقل، آناليز واريانس و رگرسيون خطى) تجزيه و تحليل شد.

\section{يافتهها}

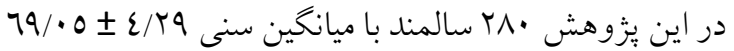

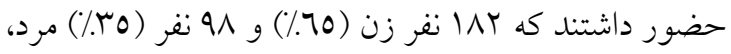
بودند. Yr/9 درصد داراى تحصيلات در حد دييلم، درصد بىسواد، ا ب درصد بالاتر از دييلم و rO/V درصد داراى تحصيلات ابتدايى، //7 درصد متأهل، ع/آ درصد همسر فوت شده و 7/2 درصد مجرد بودند و 10/N درصد از سالمندان تنها زندكى مى كردند. از بين واحدهاى مورد

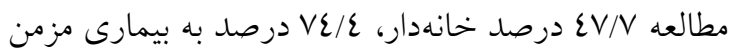

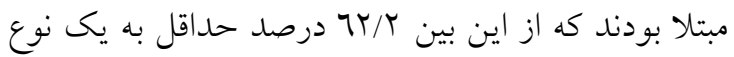
بيمارى مزمن مبتلا بودند. بالاترين درصد در بين بيمارىها

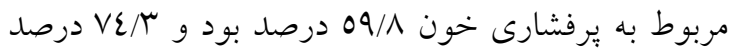

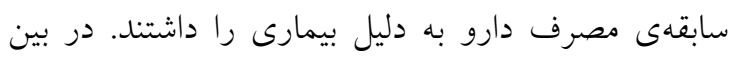

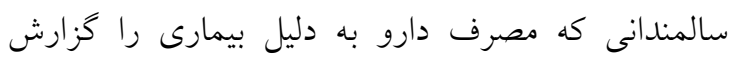

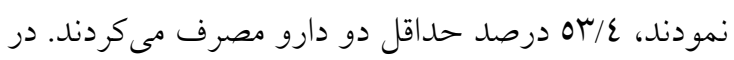

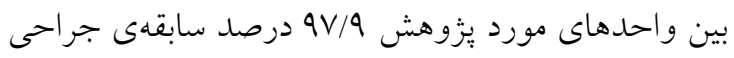

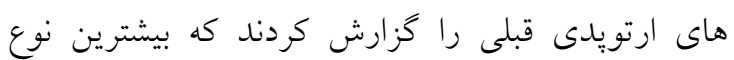

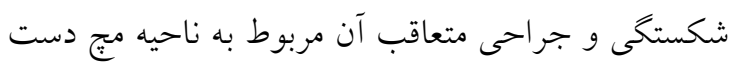

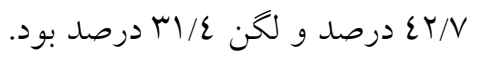

جدول شمارها: توزيع فراوانى و درصد ترس از سقوط در سالمندان مورد مطالعه سماره : توزيع

\begin{tabular}{|c|c|c|}
\hline درصد فراوانى & فراوانى & ترس از سقوط \\
\hline$\mu$ & 1 & كم (19-17) \\
\hline $1 /$ & $r$ & متوسط (T-TV ) \\
\hline $9 / / 7$. & rVI & 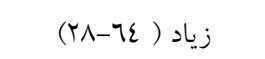 \\
\hline $1 .$. & $r \wedge$. & جمع كل \\
\hline \multicolumn{2}{|c|}{$\varepsilon \varepsilon /|V \pm V / q|$} & انحراف معيار ـ ميانخين \\
\hline \multicolumn{2}{|c|}{$\mid \Lambda-7 r$} & بيشينه - كمينه \\
\hline
\end{tabular}

بررسى نتايج جدول شمارهى r نشان داد كه متغير "سن"، "جنسيت"، "سطح تحصيلات"، "وضعيت تأهل"،

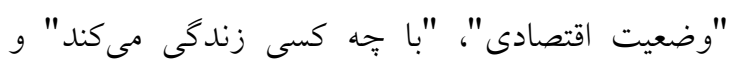

مقياس بين المللى كارآمدى در سقوط، يا به تعبير متون

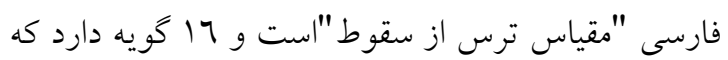

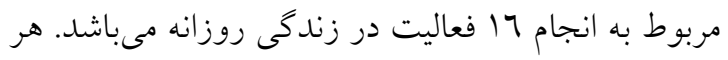

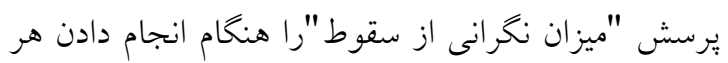

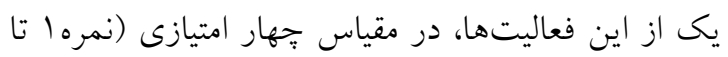

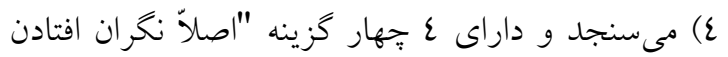

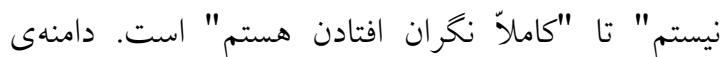
نمرات (ع 7-7 1) است و نمرات 17 19 19 به عنوان كمترين

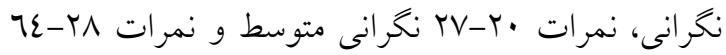

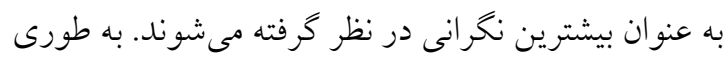
كه نمره يا امتياز بالاتر، نشان دهنده نغر انى يا ترس بيشتر است. اين مقياس توسط Yardley و همكاران در سال

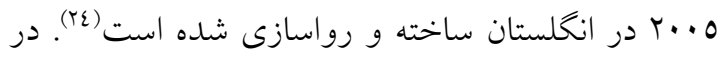
ايران نسخه ترجمه شده توسط خواجوى در سال كوسا، تحت عنوان "مقياس ترس از سقوط"، روانسنجى شده

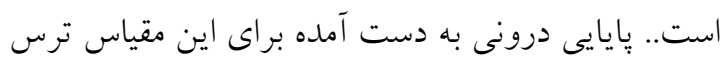

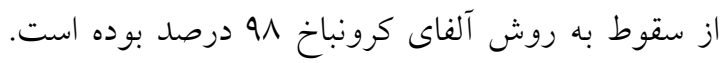

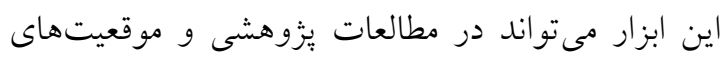

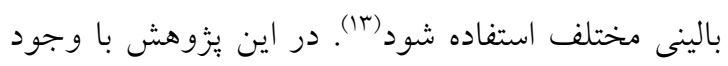

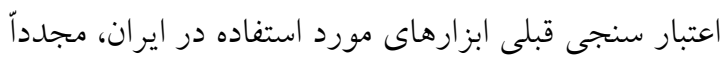

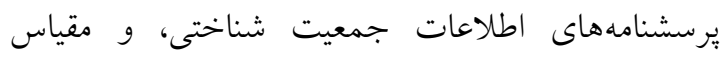
كارآمدى در سقوط در اختيار اساتيد هيئت علمى قرار

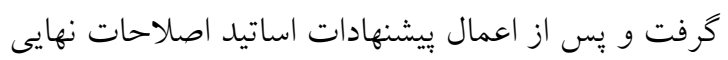
انجام و فرمهاى مذكور مورد استفاده قرار گرفت. هم:حنين

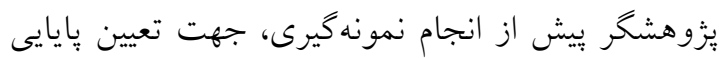

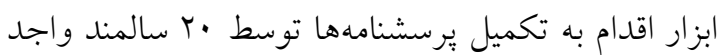
شرايط ورود به مطالعه نمود و ضريب يايايى براى مقياس

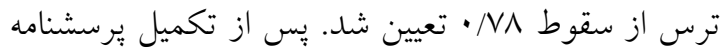
ها به صورت مصاحبه حضورى با سالمند، اطلاعات

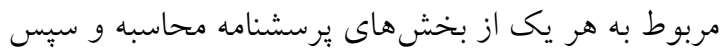
دادههاى خام در جداول اوليه تنظيم و با استفاده از نرم افزار SPSS نسخه •ب و به روش آمار توصيفى (جداول

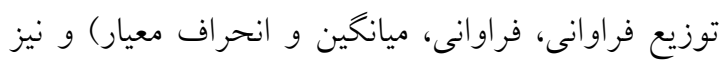


=). ترس از سقوط در سالمندان با "وضعيت اقتصادى بد" به طور معنى دارى بيشتر از سالمندان با "وضعيت اقتصادى

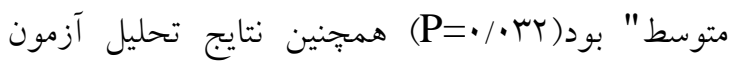
مقايسهاى شفه نشان داد ترس از سقوط در سالمندانى كه با "همسر" زندكى مى كنند به طور معنىدارى كمتر از سالمندانى است كه با "فرزند يا فرزندان" زندكى مى كنند

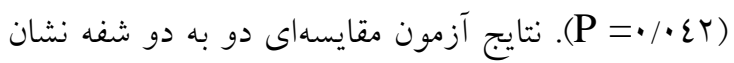
داد كه ميانگين نمره كسب شده در سالمندان خانهدار به طور معنى دارى بيشتر از شاغلين ( (P= (P = ) و بازنشسته ها
"وضعيت اشتغال" با ترس از سقوط ارتباط معنىدار آمارى داشتند (0/ P<). براى متغير سن ميانخين نمره ترس از سقوط در بازه سنى ( V• تا Vo) سال بالاتر از بقيه بازههاى سنى بود و بر اساس نتايج آزمون مقايسهاى دو به دوى شفه، ترس از سقوط در گروه (•V-70) به طور معنىدارى

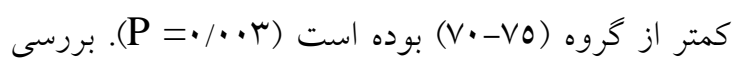
متغير "سطح تحصيلات"، بر اساس نتايج آزمون مقايسهاى شفه نشان داد كه ترس از سقوط در گروه بيسواد به طور

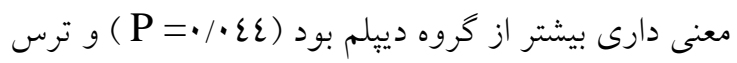
از سقوط در سالمندان "همسر فوتشده" به طور معنى

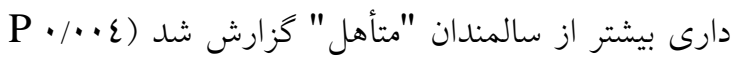

جدول شماره ז: ارتباط ترس از سقوط با ويزَّى هاى جمعيت شناختى

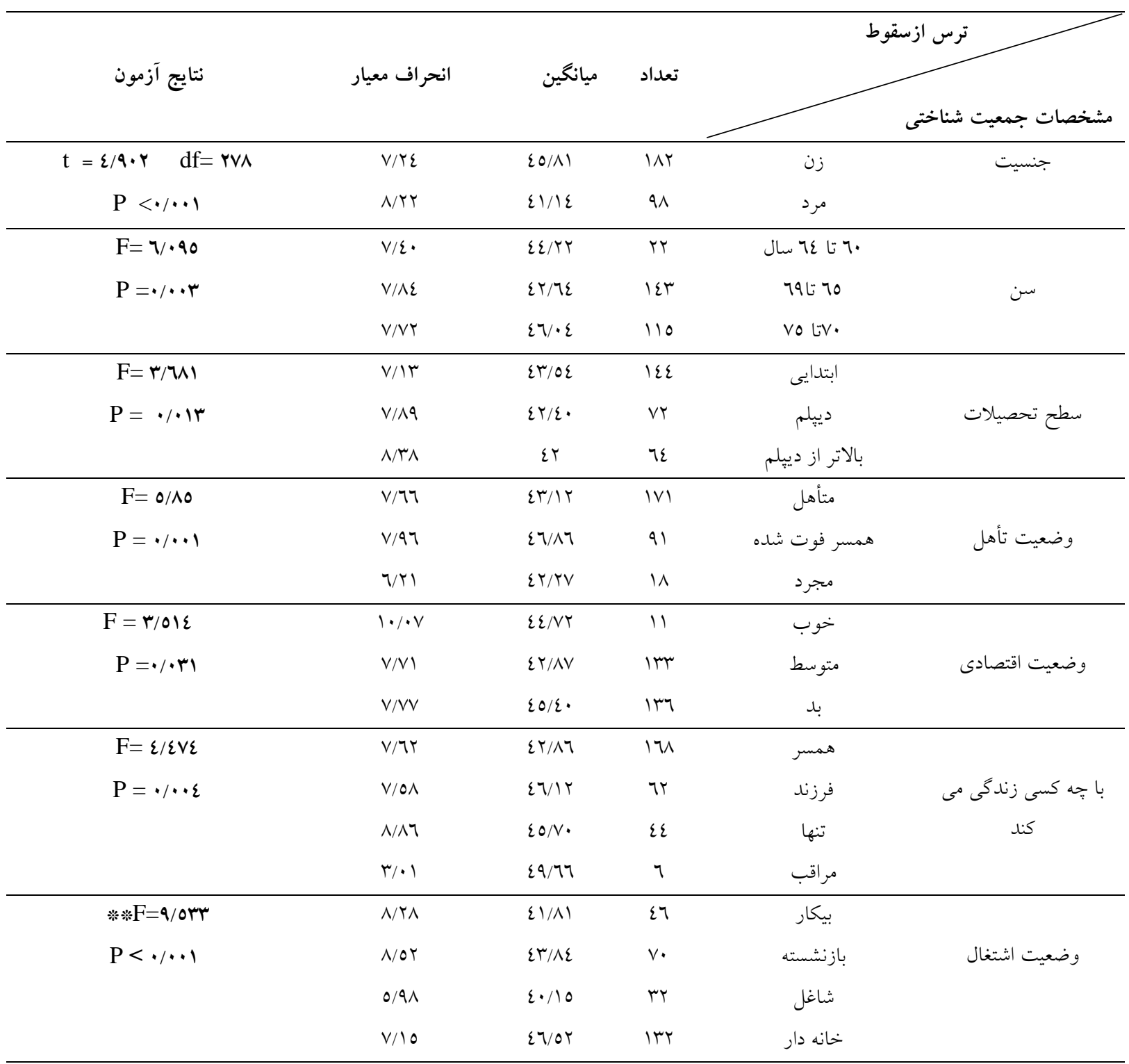


معنى دارى بيشتر از سايرين بود ( (P = P (P). نتايج نشان داد كه نمره "ترس از سقوط" در بين سالمندان داراى فشار

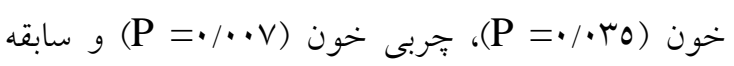

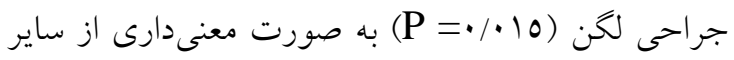

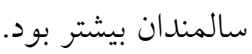

براساس نتايج جدول شمارهى rا، ترس از سقوط در سالمندانى كه بيمارى مزمن داشتند به طور معنى دارى بالاتر

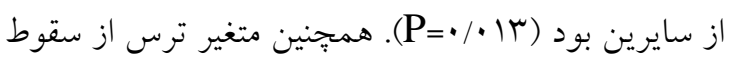

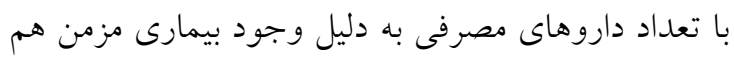

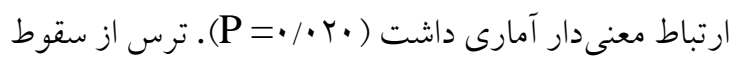
در سالمندانى كه بيش از يك بيمارى مزمن داشتند به طور

جدول شماره س: ارتباط ترس از سقوط با ويزَىهاى بالينى

\begin{tabular}{|c|c|c|c|c|c|}
\hline نتايج آزمون & انحر اف معيار & ميانخين & ت تعداد & ترس از سقوط & \\
\hline & & & & & ويزگى هاى بالينى \\
\hline$t=r / 0 . \quad d f=r V \Lambda$ & $\varepsilon / 7 V$ & so/rr & $r \cdot 9$ & دارد & بيمارى مزمن \\
\hline $\mathrm{p}=\cdot / \cdot 14$ & $\varepsilon / \wedge$. & $\varepsilon 1 / \cdot \wedge$ & vi & ن ارد & \\
\hline$t=-r / \varepsilon \wedge \varepsilon \quad$ df $=r \cdot \vee$ & $V / \varepsilon \varepsilon$ & $\varepsilon r / \Lambda r$ & $|m|$ & يك بيمارى & تعداد بيمارى مزمن \\
\hline $\mathrm{p}=\cdot / \cdot \cdot 1$ & $V / r \varepsilon$ & $\{V / 01$ & va & بيش از يك بيمارى & \\
\hline $\mathrm{t}=r / \lambda r) \quad \mathrm{df}=r \cdot V$ & $V / r u$ & $\varepsilon \mathrm{V} / \mathrm{T}$ & Iro & دارد & فشارخون \\
\hline $\mathrm{p}=\cdot / \cdot \mathrm{ro}_{0}$ & $\mathrm{~V} / \mathrm{Vq}$ & $\varepsilon r / M$ & 100 & 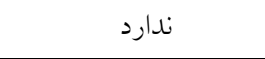 & \\
\hline $\mathrm{t}=r N \Gamma \mathrm{d} \quad \mathrm{df}=r \cdot V$ & $N / \cdots V$ & $\varepsilon N / V_{0}$ & $r$. & دارد & جربى خون \\
\hline \multirow[t]{2}{*}{$\mathrm{P}=\cdot / \cdot v$} & $v / r q$ & $\varepsilon \varepsilon / 77$ & ro. & 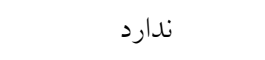 & \\
\hline & $0 / 10$ & $\varepsilon r / 0$ & 7 & يك دارو & \\
\hline \multirow{4}{*}{$\begin{array}{l}\mathrm{F}=r / \cdot r r \\
\mathrm{P}=\bullet / \cdot r .\end{array}$} & $V / \varepsilon V$ & $\varepsilon r / 99$ & 11 & 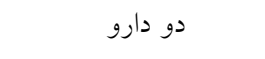 & \\
\hline & $1 / r q$ & $\varepsilon \varepsilon / v \wedge$ & $1 \varepsilon$ & سه دارو & داروهاى مصرفى \\
\hline & V/rT & $\varepsilon \varepsilon / \varepsilon$. & 10 & جها دارو & \\
\hline & $\mathrm{V} / \mathrm{rl}$ & $\varepsilon V / M$ & r & ينج دارو و بيشتر & \\
\hline $\mathrm{t}=r / \varepsilon \circ \varepsilon \quad \mathrm{df}=r V r$ & $V / \varepsilon$. & $O T / N O$ & M & دارد & جراحى لكن \\
\hline $\mathrm{P}=\cdot / \cdot 10$ & $V / 91$ & $\varepsilon r / T V$ & 194 & 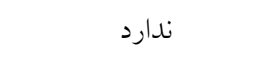 & \\
\hline
\end{tabular}

واحد بيشتر از مردان و در مجردين به اندازه بr// واحد نسبت به همسر فوت شدهها كمتر بود. اين متغير در بهرد

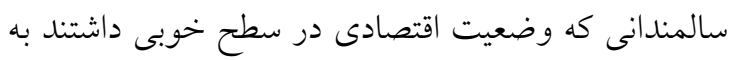
اندازه سr/1/ واحد نسبت به سالمندان با وضعيت اقتصادى

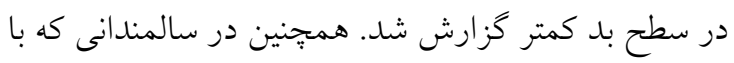
همسر و سالمندانى كه با فرزند زندگى مى كردند به ترتيب

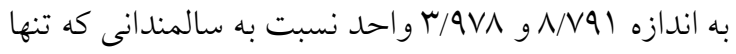
زندكى مىكردند كمتر بود. متغير "ترس از سقوط" در سالمندانى كه داراى بيمارى مزمن و همجِنين فشارخون بالا
باتوجه به نتايج جدول شماره ع و نتايج آزمون رگرسيون خطى، متغيرهاى جنسيت زن، مجرد بودن، فشار خون،

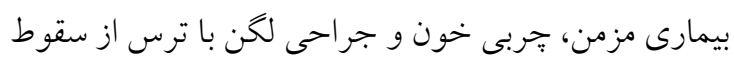

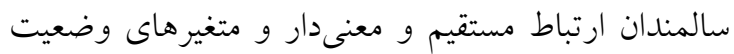
اقتصادى خوب و زندگى با همسر و فرزندان با ترس از

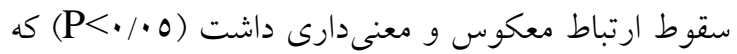
از بين اين متغيرها، بيشترين اثر را متغيرهاى بيمارى مزمن،

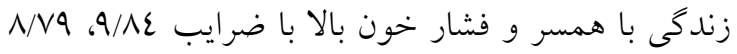

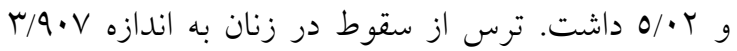


سالمندان و سالمندانى كه جراحى لكن داشتند اين متغير را به اندازه سN// واحد بيشتر از سايرين كزارش كردند.

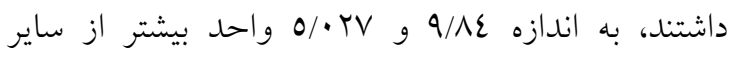

سالمندان بود و سالمندانى كه جربى خون بالا داشتند، ميزان ترس از سقوط را به اندازه جاح/r واحد بيشتر از ساير

جدول شماره ع: نتايج تحليل ركرسيون خطى براى بررسى اثر مشخصات جمعيت شناختى بر ترس از سقوط در سالمندان بعد از جراحى

\begin{tabular}{|c|c|c|c|c|c|c|}
\hline $\mathrm{R}^{2}$ & P-value & آماره & B & ضريب B & & متغيرهاى مستقل \\
\hline & & & & & 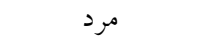 & جنسيت \\
\hline & $\cdot / \cdot V$ & T/NTO & • & $r / q \cdot V$ & زن - ان & \\
\hline & & & & & بالاتر از دييلم & \\
\hline & $\cdot / 200$ & $\cdot / \vee \varepsilon \Lambda$ &.$/ 11 \mathrm{r}$ & I/NVO & 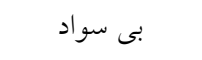 & سطح تحصيلات \\
\hline & $\cdot / 9 \sum 1$ & $\cdot / \cdot v \varepsilon$ &.$/ 1$ & $\cdot / 187$ & ابتدايى & \\
\hline & $\cdot / 170$ & $-\cdot / l V$ & $-\cdot / \cdot 1 \mathrm{~V}$ & $-\operatorname{MrTT}$ & دييلم & \\
\hline & & & & & همسر فوت شده & \\
\hline & $\cdot / 09 \mathrm{~V}$ & $-\cdot / 0 r$. &.$- / \cdot$ ro & $\varepsilon / 90 \wedge$ & متأهل & وضعيت تأهل \\
\hline & $\cdot / \cdot 7$ & $-Y / V V I$ & $-\cdot / 0 \varepsilon 0$ & $-1 / 1 Y 7$ & مجرد & \\
\hline & & & & & بد & \\
\hline \multirow[t]{18}{*}{$\cdot /$ Tor } & $\cdot / \cdots v$ & $-\cdot /$ V77 & $-\cdot / \cdot \varepsilon V$ & -1/9T & خوب & وضعيت اقتصادى \\
\hline & $\cdot / \varepsilon \varepsilon 0$ & $-\cdot / 9 \cdot 1$ & -.1 .09 & $-\cdot / 9 \varepsilon 1$ & متوسط & \\
\hline & & & & & تنها & \\
\hline & $\cdot / \cdots 7$ & $-Y / V V I$ & $\cdot 10<0$ & $-\Lambda / \vee 91$ & همسر & با جهه كسى زندگى مى كند \\
\hline & $\cdot / \cdot 1 r$ & - Y/OrI & $-\cdot / r \cdot 9$ & $-r / 9 V \wedge$ & فرزند يا فرزندان & \\
\hline & $\cdot / \varepsilon \varepsilon 1$ & $\cdot / \mathrm{VI}$ & $\cdot / \cdot \varepsilon \Lambda$ & $r / 7 T V$ & مراقب & \\
\hline & & & & & خانه دار & \\
\hline & $\cdot / \cdot \wedge \varepsilon$ & $-1 / N T^{-}$ & $-\cdot / T \wedge$ & $-r / I 7 V$ & شاغل & \\
\hline & $\cdot / 9 \cdot 9$ &.$- / 110$ & $-\cdot / \cdot 1 \cdot$ & $-\cdot / r \cdot 7$ & بيكار & وضعيت اشتغال \\
\hline & • Mro & $-\cdot / 917$ & $-\cdot / 1 \cdot 1$ & $-1 / \wedge \varepsilon Y$ & بازنشسته & \\
\hline & & & & & 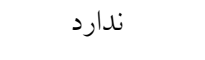 & بيمارى مزمن \\
\hline &.$/ \cdot r$ & r/l &.$/ 0 \varepsilon$ & $9 / \wedge \sum 7$ & دارد & \\
\hline & & & & & 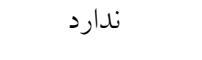 & فشار خون \\
\hline & $\cdot \cdots 1$ & $r / r \varepsilon \wedge$ &.$/ 19 \mathrm{~V}$ & $0 / \cdot T V$ & 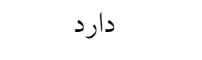 & \\
\hline & & & & & 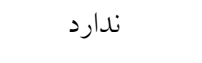 & جربى خون \\
\hline & $.1 \cdot 10$ & $r / \varepsilon \varepsilon V$ & $\cdot / 1 \varepsilon r$ & $r / 717$ & دارد & \\
\hline & & & & & 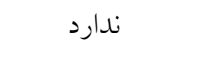 & جراحى لكن \\
\hline & $\cdot / \cdot T r$ & $r / r \cdot 1$ & $\cdot / M \Lambda$ & $r / \Lambda \wedge r$ & دارد & \\
\hline
\end{tabular}

درمانخاههاى بيمارستانهاى منتخب دانشخاه علوم يزشكى ايران در سال 9V I انجام شد. نتايج نشان داد كه $91 / 7$ درصد سالمندان ترس بالايى از سقوط داشتند. همجنين بين
بحث و نتيجه تيرى اين مطالعه با هدف تعيين ترس از سقوط در سالمندان بعد از جراحى ارتويدى ناشى از سقوط مراجعه كننده به 
دهد (10). همحزنين يزّوهش حاضر بر روى سالمندانى انجام

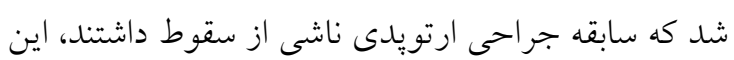

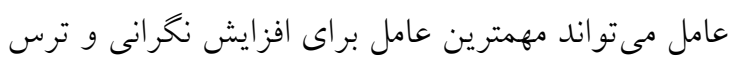

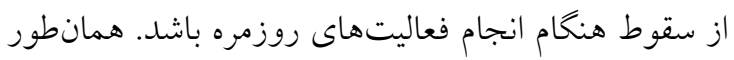

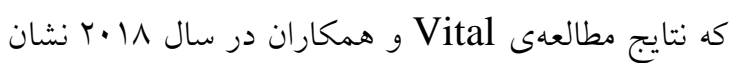

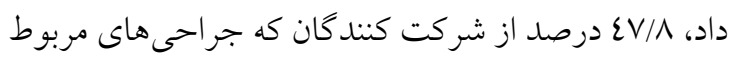
به تعويض مفصل Hip ناشى از شكستكى داشتند،

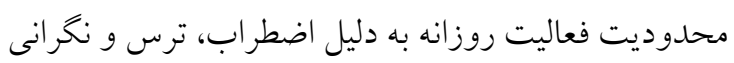
ناشى از سقوط (0/0.1/) را تجربه كردند (19).

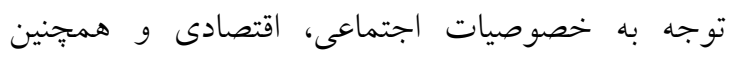
فرهنگى، سطح تحصيلات مى تواند سطح بالاى ترس از به از

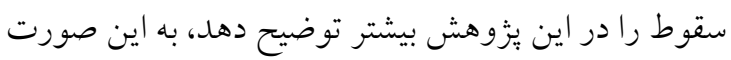

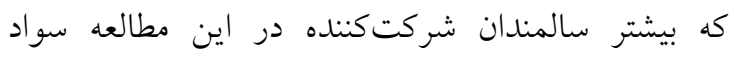

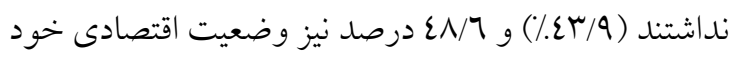
را بد گزارش كردند. علاوه بر اين VV/V درصد از شركت كنندها خانهدار بودند كه بر اساس مطالعهى

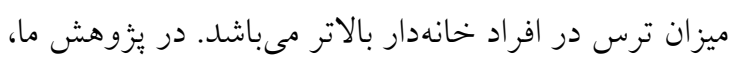

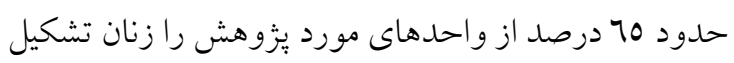
دادند كه بر اساس مطالعهى Kumar و همكاران، ميزان ترس از سقوط در زنان بيش از مردان مىباشد (17).

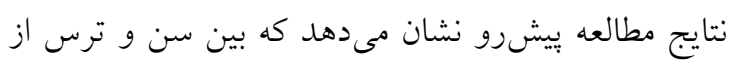

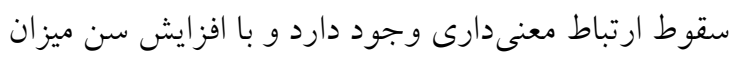

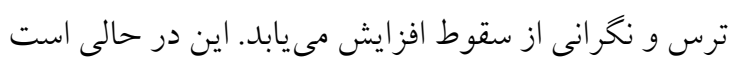
كه در مطالعات انجام شده توسط و Kressig و همكاران (r.) و Andresen و همكاران("(1)، ارتباط معنى دارى بين سن سن و ترس از سقوط يافت نشد. اما مطالعهى Murphy)

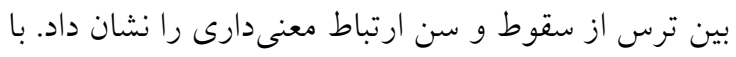
توجه به تناقض در اين مورد، نياز به مطالعات بيشترى در اين زمينه خواهد بود. در ئزوهش حاضر بين جنسيت و ترس از سقوط ارتباط معنى دارى مشاهده شد، به طورى كه

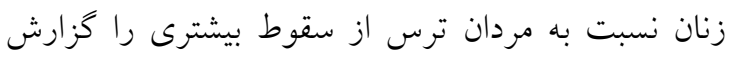

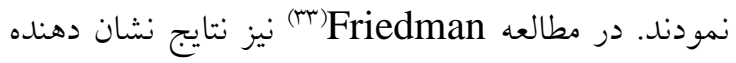

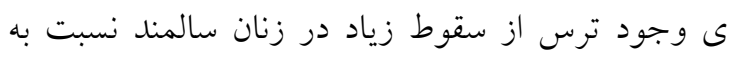

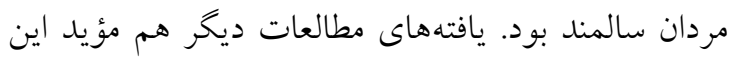

"ترس از سقوط" با متغيرهاى سن، جنسيت، سطح تحصيلات، وضعيت تاهل، وضعيت اقتصادى، وضعيت

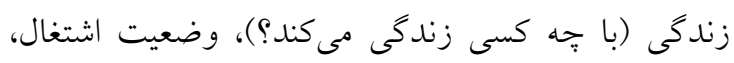

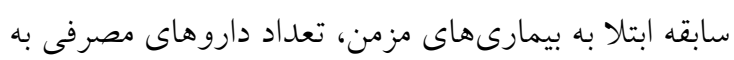

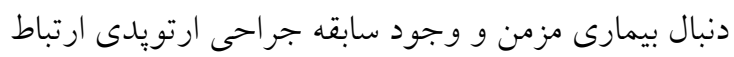

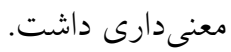
نتيجه يك مطالعه مرورى شيوع تنش و استرس و ترس از

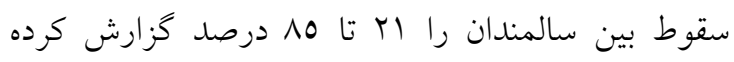

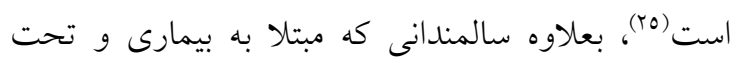

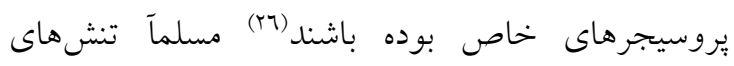

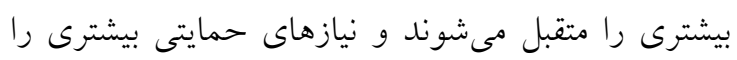
طلب مىنمايند و ضرورى است اين عوامل در سالمندان

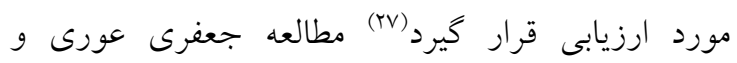
همكارانش نشان داد كه •7 درصد سالمندان نخرانى

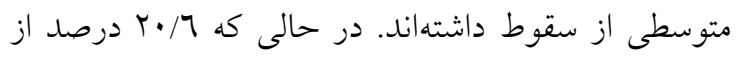

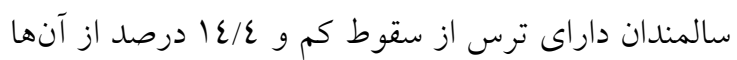

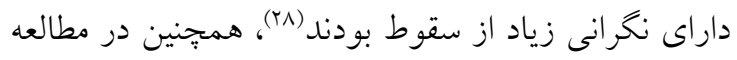
Kumar

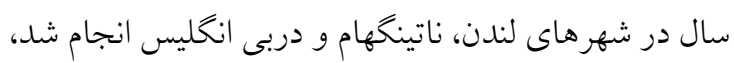
19 درصد از شركت كنندكان ترس و نخرانى بالايى از سقوط را گزارش كردند (17). بر اساس مطالعه ى Akosile

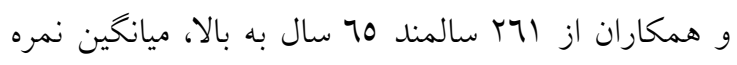

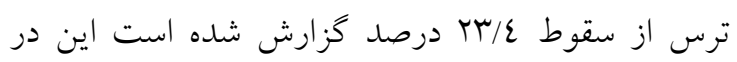

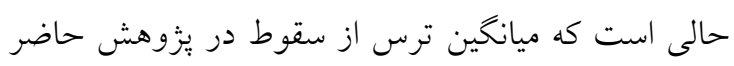

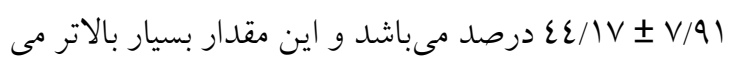
باشد (V) بالا بودن ميزان ترس از سقوط در سالمندان مورد

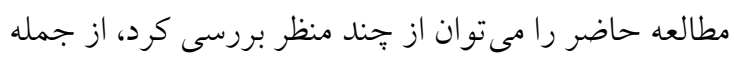
بالا بودن ميانكين سنى سالمندان شركت كننده در مطالعه رونه

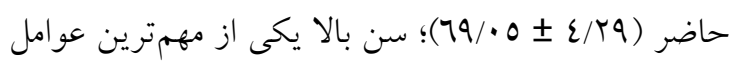

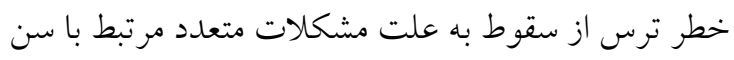

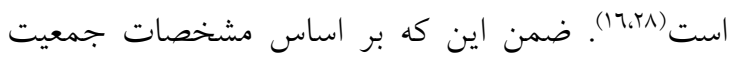

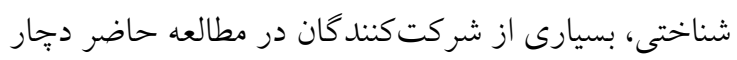

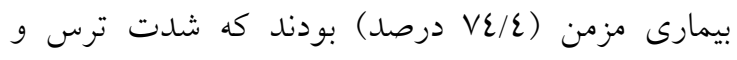

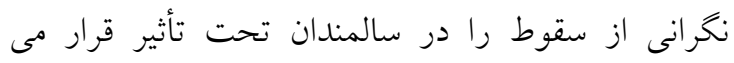


سالمندان بايد مورد توجه قرار بخيرد. نتايج حاصل از اين مطالعه و توجه به عوامل جمعيت شناختى مؤثر و مرتبط با متغير "ترس از سقوط" مىتواند در حيطه آموزش و مديريت يرستارى و همجينين در بالين مورد توجه قرار بحيرد. كتترل نخرانى و ترس از سقوط نياز به مداخلات روانشناختى و مشاورهاى دارد، بنابراين اين مهم ميتواند در برنامههاى آموزشى حين ترخيص و در مراكز مراقبت سالمندان تحت جراحى ارتويدى مورد توجه قرار كيرد.

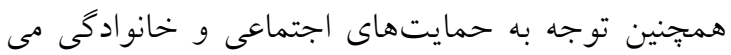
تواند به عنوان مسائل مهم و قابل تعميم در سالمندان مطرح شود. از محدوديتهاى اين طرح، وجود شرايط نامطلوب براى مصاحبه با سالمند بود كه به دليل ازدحام جمعيت

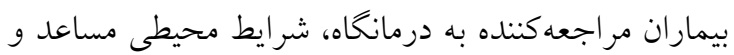
آرامى وجود نداشت كه اين عامل مىتواند در ياسخخويى و نخرانى سالمندان تأثير گذار باشد، بنابراين شايسته است مطالعهاى با اين مضمون بر روى سالمندان بسترى كه شر ايط محيطى مناسبترى دارند، صورت يذيرد.

تعارض منافع: دراين يزوهش هيج گونه تعارض منافعى

$$
\text { از سوى نويسندگان گزارش نمىشود. }
$$

\section{تقلدير و تشكر}

نويسند گان مقاله مراتب تشكر و قدردانى خود را از تمامى سالمندان محترم شركت كننده در اين يزوهش اعلام مى دارند. هم جنين از معاونت يزوهشى دانشگاه علوم يزشكى و خدمات بهداشتى درمانى ايران كه حامى مالى اين طرح با كد 12731-3-3-37 بودند قدردانى مى گردد.
مطلب است كه سقوط و ترس از سقوط در زنان و همجنين در سنين بالاتر، بيشتر است كه احتمالاّ مىتواند مربوط به له شيوع يوكى استخوان در زنان باشد (عَr). بر اساس نتايج مطالعهى سالاروند و بيرجندى وجود بيمارىهاى مزمن با ميزان ترس از سقوط ارتباط معنى دار

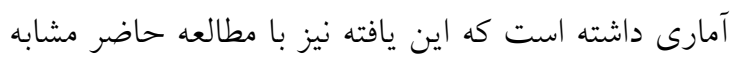
مىباشد. در مطالعه سالاروند، بين تعداد داروهاى مصرفى و ميزان ترس از سقوط هم ارتباط وجود داشت(ro) كه در مطالعه بيش رو هم اين ارتباط مشهود بود، در واقع هرجيه بيمار داروهاى بيشترى مصرف كند، بيشتر در معرض خطر اشتباهات يا تداخلات دارويى كه مىتوانند در مسئله سقوط و ترس از آن دخيل باشند، قرار مى گيرد ("rr). در اين مطالعه، ارتباط بين نوع داروهاى مصرفى و همجنين تأثير مصرف تجمعى جند دارو با هم بررسى نشده است و بيشنهاد مى شود مطالعات بيشترى در اين زمينه صورت بخيرد. هرجه. حمايت اجتماعى بيشتر باشد، خطر سقوط و ترس از آن

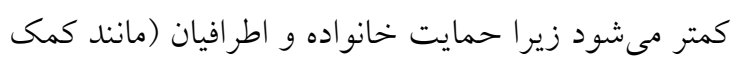
در جابجا كردن اجسام، يا كتترل مناطقى كه احتمال سقوط وجود دارد) در بيشتر موارد خطر سقوط و ترس از

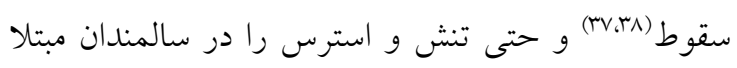

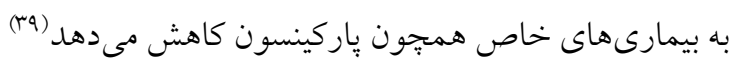
علاوه بر اينكه ابتلا به بيمارى و انجام يروسيجرهاى درمانى

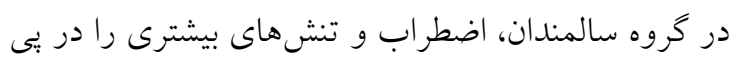
دارد و متعاقباً نيازهاى حمايتى و خانو ادكى بيشترى را طلب مىنمايد (r7). باتوجه به اين كه درصد قابل توجهى از سالمندان مورد

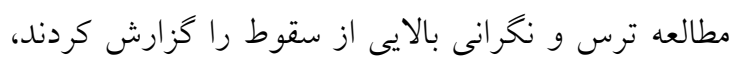

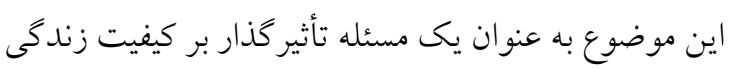

\section{References}

1. World Health Organization. 10 Facts On Ageing And The Life Course. Available: https://www.who.int/features/factfiles/ageing/ageing_facts/en/ [Accessed 3 March 2018].

2. Statistical Center Of Iran. detailed results of the Population and Housing Census. 2016. , Available: http://www.amar.org.ir/english/Population-and-Housing-Censuses

3. World Health Organization. Global Health and Aging Report. 2011, Available: https://www.who.int/ageing/publications/global_health.pdf.ua=1. 
4. Orces $\mathrm{CH}$. Prevalence and determinants of fall-related injuries among older adults in Ecuador. Curr Gerontol Geriatr Res. 2014;2014:1-7.

5. Lopes KT, Costa DF, Santos LF, Castro DP, Bastone AC. Prevalence of fear of falling among a population of older adults and its correlation with mobility, dynamic balance, risk and history of falls. Braz J Phys Ther. 2009;13(3):223-9.

6. Hatamabadi H, Rafieenejad A, Moghaddam MA, Sum S. A study on consequences of fall among elderly people referred to Emam Hossein hospital in Tehran city during 2010-2011. SALMAND. 2014;9(1):54-61. [Persian]

7. Raoufi S. Study of the causes of the fall of the elderly in Aligudarz city in 2006. Quarterly journal of Lorestan University of Medical Sciences. 2006);2(4.5): 48-54. [Persian]

8. da Costa EM, Pepersack T, Godin I, Bantuelle M, Petit B, Levêque A. Fear of falling and associated activity restriction in older people. results of a cross-sectional study conducted in a Belgian town. Archives of public health. 2012;70(1):1-8.

9. Akbarian. M., Epidemiology and Importance of Osteoporosis, Tehran; Andishamand Publication, 2002; P: 61.

10. Soheili Azad AA, Yavari H, Azami M. Assessment of the costs of hip fractures in patients who referred to orthopedic clinic of Sina Hospital. Razi Journal of Medical Sciences. 2005 Dec 15;12(47):83-92.[Persian]

11. Coimbra AM, Ricci NA, Coimbra IB, Costallat LT. Falls in the elderly of the family health program. Arch Gerontol Geriatr. 2010;51(3):317-22.

12. Pang MY, Eng JJ. Fall-related self-efficacy, not balance and mobility performance, is related to accidental falls in chronic stroke survivors with low bone mineral density. Osteoporosis international. 2008;19(7):919-27.

13. Khajavi D. Validation and reliability of Persian version of fall efficacy scale-international (FESI) in community-dwelling older adults. Iranian Journal of Ageing. 2013;8(2):39-47. [Persian]

14. Patel KV, Phelan EA, Leveille SG, Lamb SE, Missikpode C, Wallace RB, Guralnik JM, Turk DC. High prevalence of falls, fear of falling, and impaired balance in older adults with pain in the United States: findings from the 2011 National Health and Aging Trends Study. J Am Geriatr Soc. 2014;62(10):1844-52.

15. Wijlhuizen GJ, de Jong R, Hopman-Rock M. Older persons afraid of falling reduce physical activity to prevent outdoor falls. Preventive medicine. 2007;44(3):260-4.

16. Kumar A, Carpenter H, Morris R, Iliffe S, Kendrick D. Which factors are associated with fear of falling in community-dwelling older people?. Age and ageing. 2014;43(1):76-84.

17. Akosile CO, Anukam GO, Johnson OE, Fabunmi AA, Okoye EC, Iheukwumere N, Akinwola MO. Fear of falling and quality of life of apparently-healthy elderly individuals from a Nigerian population. J Cross-Cult Gerontol. 2014 Jun 1;29(2):201-9.

18. Deshpande N, Metter EJ, Lauretani F, Bandinelli S, Ferrucci L. Interpreting fear of falling in the elderly: what do we need to consider?. J Geriatr Phys Ther. 2009;32(3):91-96.

19. Zijlstra GA, Van Haastregt JC, Van Eijk JT, van Rossum E, Stalenhoef PA, Kempen GI. Prevalence and correlates of fear of falling, and associated avoidance of activity in the general population of community-living older people. Age and ageing. 2007;36(3):304-9.

20. Filiatrault J, Belley AM, Laforest S, Gauvin L, Richard L, Desrosiers J, Parisien M, LorthiosGuilledroit A. Fear of falling among seniors: a target to consider in occupational and physical therapy practice?. Phys Occup Ther Geriatr. 2013;31(3):197-213.

21. Morowatisharifabad MA, Shakeri-Mobarakeh T, Sharifabad V, Akbar A, Bidaki R, Asgari-Shahi M, Rezaeipandari H. Fear of Falling and Social Participation in the Elderlies in Mobarakeh, Isfahan Province, Iran. Elderly Health Journal. 2017;3(1):42-9.

22. Hill KD, Wee E, Margelis S, Menz HB, Bartlett J, Bergman NR, McMahon S, Hare DL, Levinger P. Falls in people prior to undergoing total hip or total knee replacement surgery: Frequency and associated factors. Journal of Clinical Gerontology and Geriatrics. 2016;7(4):146-52. 
23. Borhaninejad V, Rashedi V, Tabe R, Delbari A, Ghasemzadeh H. Relationship between fear of falling and physical activity in older adults. medical journal of mashhad university of medical sciences. 2015;58(8):446-52. [Persian]

24. Yardley L, Beyer N, Hauer K, Kempen G, Piot-Ziegler C, Todd C. Development and initial validation of the Falls Efficacy Scale-International (FES-I). Age and ageing. 2005;34(6):614-9.

25. Scheffer AC, Schuurmans MJ, Van Dijk N, Van Der Hooft T, De Rooij SE. Fear of falling: measurement strategy, prevalence, risk factors and consequences among older persons. Age and ageing. 2008;37(1):19-24.

26. Haghparast A, Hashemi B, Eivazi MT. Influence of compensator thickness, field size, and off-axis distance on the effective attenuation coefficient of a cerrobend compensator for intensitymodulated radiation therapy. Medical Dosimetry. 2013;38(1):25-9.

27. Karamivand VA, Bastani FA, Haghani HA. Support Needs of Urban and Rural Elders in Kermanshah City, Iran. Journal of Client-Centered Nursing Care. 2018;4(1):21-8. [Persian]

28. Jafari Ori M, Nasiri KH, Mehrtak M, T Ghezlzah N, Aryapoor S. The effect of a multidimensional fall prevention program on static and dynamic balance in nursing homes in Tehran. The Journal of Urmia Nursing and Midwifery Faculty. 2015;13(5):367-76. [Persian]

29. Vital IC, Cameron LE, da Cunha TR, Santos CI. Information as an Instrument of Care to Patients Undergoing Orthopedic Surgery. Cogitare Enferm. 2018;23(1):e51192.

30. Kressig RW, Wolf SL, Sattin RW, O'Grady M, Greenspan A, Curns A, Kutner M. Associations of demographic, functional, and behavioral characteristics with activity-related fear of falling among older adults transitioning to frailty. J Am Geriatr Soc. 2001;49(11):1456-62.

31. Andresen EM, Wolinsky FD, Miller JP, Wilson MM, Malmstrom TK, Miller DK. Cross-sectional and longitudinal risk factors for falls, fear of falling, and falls efficacy in a cohort of middle-aged African Americans. The gerontologist. 2006;46(2):249-57.

32. Murphy SL, Williams CS, Gill TM. Characteristics associated with fear of falling and activity restriction in community-living older persons. J Am Geriatr Soc. 2002;50(3):516-20.

33. Friedman SM, Munoz B, West SK, Rubin GS, Fried LP. Falls and fear of falling: which comes first? A longitudinal prediction model suggests strategies for primary and secondary prevention. $J$ Am Geriatr Soc. 2002;50(8):1329-35.

34. Luxton T, Riglin J. Preventing falls in older people: a multi-agency approach. Nursing Older People (through 2013). 2003;15(2):18.

35. Salarvand SH, Birjandi M. Factors related to falling down in older adults. Iran J Nursing. 2009;22(61):51-60. [Persian]

36. Theodos P. Fall prevention in frail elderly nursing home residents: a challenge to case management: part I. Professional Case Management. 2003;8(6):246-51.

37. Huang HC, Gau ML, Lin WC, George K. Assessing risk of falling in older adults. Public Health Nursing. 2003;20(5):399-411.

38. Bastani F, Birjandi M, Haghani H, Sobhan MR. Factors Associated With Fear of Falling and Functional Independence in Older Adults in Iranian Nursing Homes. Journal of Client-Centered Nursing Care. 2016;2(3):135-44. [Persian]

39. Soleimani MA, Bastani F, Negarandeh R, Greysen R. Perceptions of people living with Parkinson's disease: a qualitative study in Iran. Br J Community Nurs. 2016 Apr 2;21(4):188-95. 